\title{
UNFOLDED PROTEIN RESPONSE IS ACTIVATED IN THE HEARTS OF CATECHOLAMINERGIC POLYMORPHIC VENTRICULAR TACHYCARDIA (CPVT) MICE
}

\author{
Rigers Bakiu
}

Department of Animal Production, Agricultural University of Tirana, Koder Kamez, Tirane, Albania

\section{ODGOVOR NESAVIJENIH PROTEINA JE AKTIVIRAN U SRCU MIŠEVA SA GENETSKI IZAZVANOM KATEHOLAMINERGIČKOM POLIMORFNOM VENTRIKULARNOM TAHIKARDIJOM

\section{ABSTRACT}

Isoform 2 of calsequestrin (CSQ2) is the main calciumbinding protein of the sarcoplasmic reticulum (SR) and is expressed in both cardiac and skeletal muscle. CSQ2 acts as an $S R$ calcium $\left(\mathrm{Ca}^{2+}\right)$ sensor and regulates $S R \mathrm{Ca}^{2+}$ release via interactions with triadin, junctin, and the ryanodine receptor. Various mutations of the csq2 gene lead to altered $\mathrm{Ca}^{2+}$ release and contractile dysfunction and contribute to the development of arrhythmias and sudden cardiac death in young individuals affected by CPVT. Transgenic mice carrying one of the identified CSQ2 point mutations (R33Q) associated with CPVT were developed, and a drastic reduction in the mutated protein was observed. Following a biomolecular approach, several analyses were performed using different antibody treatments to identify when the reduction of CSQ2 begins, to unveil the mechanism involved in the reduction of CSQ2 and to verify whether other proteins are affected by the presence of the mutated protein. The results of this study showed that mutated CSQ2 levels decreased soon after birth, in conjunction with decreased levels of other important junctional SR proteins, including triadin (TD). The up-regulation of proteins associated with the unfolded protein response (UPR) was also observed, and the ATF6dependent pathway was activated by the UPR. The presence of the R33Q mutation induced the decrease of CSQ2 via UPR activation and subsequent proteasomal degradation.

Keywords: Calsequestrin, CPVT, ERAD, UPR, Triadin, Chaperones.

\section{SAŽETAK}

Izoforma 2 kalsekvestrina (CSQ2) je glavni kalcijum-vezujući protein sarkoplazmatskog retikuluma (SR) i nalazi se kako u srčanom tako i u skeletnom mišiću. CSQ2 deluje kao kalcijumski receptor koji reguliše oslobađanje $\mathrm{Ca}^{2+}$ jona iz SR, putem interakcije sa triadinom, junktinom $i$ rianodinskim receptorom. Razlicite mutacije csq2 gena mogu da izazovu poremećaje u oslobađanju $\mathrm{Ca}^{2+}$ i time kontraktilne funkcije, čime doprinose ravoju aritmija $i$ iznenadnoj srčanoj smrti mladih osoba koje boluju od kateholaminergičke polimorfne ventrikularne tahikardije (CPVT). Razvojem transgenetskih miševa sa CSG2 point mutacijom (R33Q) i CPVT-om, primećen je drastičan pad nivoa mutiranog proteina. Prateći biomolekularni pristup, nekoliko analiza je izvedeno, koristeći tretman razlicitim antitelima, sa ciljem da se otkrije kada počinje smanjenje nivoa CSQ2, rasvetli mehanizam uključen u redukciju CSQ2 $i$ ispita da li prisustvo mutiranih proteina utiče i na druge proteine. Rezultati ove studije su pokazali da se nivoi mutiranih CSQ2 smanjuju ubrzo nakon rodjenja, što je udruženo sa smanjenim nivoom ostalih značajnih proteina SR, uključujući triadin (TD). Takođe je primećeno da odgovor nesavijenih proteina može biti povezan sa ushodnom regulacijom proteina $i$ aktivacijom ATF-6 zavisnog signalnog puta. Prisustvo R33Q mutacije je izazvalo smanjenje nivoa CSQ2 putem aktivacije odgovora nesavijenih proteina i posledične proteozomalne degradacije.

Ključne reči: Kalsekvestrin, CPVT, ERAD, UPR, triadin, haperoni 


\section{INTRODUCTION}

Sudden cardiac death causes approximately 300,000 deaths each year in Europe and the U.S.A.; ventricular fibrillation is the underlying mechanism of most diseases that lead to sudden cardiac death. The identification of mechanisms causing life-threatening arrhythmias is a major priority in the biomedical field $(1,2)$. Given the crucial role of $\mathrm{Ca}^{2+}$ in the generation of focal arrhythmias, the mechanisms responsible for $\mathrm{Ca}^{2+}$ homeostasis in the SR of cardiomyocytes are of great importance in cardiac pathophysiology. The discovery of SR proteins, such as ryanodine receptor (RyR) and CSQ, that play key roles in the mechanisms behindunderlying inherited arrhythmia syndromes such as CPVT emphasises the link between changes in intracellular $\mathrm{Ca}^{2+}$ homeostasis and arrhythmogenesis $(3,4)$. CPVT occurs at a young age as a result of exercise or emotional stress, is characterised by recurrent syncope, convulsions, and cardiovascular collapse and can lead to sudden death (4). Homozygous CSQ2 mutations (5) explain 3\% of all CPVT cases, while approximately $50 \%$ of patients have mutations in RyR2 (6). Song and colleagues (7) have demonstrated the existence of common pathophysiological mechanisms caused by alterations in RyR2 and/or CSQ2 that relate to CPVT.

To close the gap between experimental and clinical data, it is extremely important to develop experimental animal models that phenotypically copy the clinical disease. This "challenge" is particularly demanding in arrhythmogenic diseases because of the large differences between humans and mice in ion channel profiles and action potential durations. CPVT has proven to be an exception in comparison with other hereditary diseases, represented by transgenic mice that have a low level of analogy with the phenotype of human patients . Knock-in (KI) RyR2-R4497 (8) and CASQ2R33Q (9) mouse models currently exist as autosomal dominant and recessive CPVT models, respectively. The delicate balance that regulates the flow of calcium through the membrane of the SR in cardiomyocytes and, consequently, the balance between cytoplasmic and extracellular $\mathrm{Ca}^{2+}$ play critical roles in ensuring cell viability, preserving normal contractile function and providing heart rate stability. The SR, an important cell organelle, and the two SR proteins RyR and CSQ play crucial roles in these processes. In fact, the mechanism associated with depolarisation of the muscle fibre plasma membrane followed by release of $\mathrm{Ca}^{2+}$ from the $\mathrm{SR}$, called coupling excitation-contraction (EC), depends on the plasma membrane calcium channel $\mathrm{L}$ type receptor dihydropyridine (DHPR) and the RyR receptor present on the membrane of SR terminal cisternae; both are $\mathrm{Ca}^{2+}$ release units (CRUs) (10). Calsequestrin is the major $\mathrm{Ca}^{2+}$-binding protein present in the junctional SR of skeletal and cardiac muscle fibres. In mammals, there are two CSQ isoforms encoded by different genes: the skeletal isoform CSQ1 is expressed in fast- and slow-twitch skeletal muscle, while the cardiac isoform CSQ2 is expressed in both cardiac and skeletal muscle. Some CSQ2 mutations seem to affect protein synthesis, leading to the reduction or absence of CSQ2 in the heart (9), while other mutations seem to induce the expression of defective proteins, which show altered abilities to bind $\mathrm{Ca}^{2+}$ and/or to perform their proper function (9). All experimental evidence has implicated mechanisms of posttranscriptional regulation. Among the possible mechanisms involved in this regulation is endoplasmic reticulum (ER)-associated protein degradation (ERAD), which is responsible for the degradation of proteins synthesised at the ER lumen via the proteasome following activation of an ER stress response pathway.

Various factors can activate an ER stress response pathway. One such factor, the presence of incorrectly folded proteins, activates the unfolded protein response (UPR). To reach a possible explanation for the drastic reduction of CSQ2-R33Q in 8-week- old adult mice (9), the first objective was to determine at what age the CASQ2 reduction began. The other objectives were to determine whether any other proteins were affected by the reduced levels of CSQ2 and to reveal the mechanisms involved in the reduction of CSQ2-R33Q.

\section{MATERIALS AND METHODS}

Molecular analyses were performed on total heart homogenates of $4 \mathrm{wt} / \mathrm{wt}$ and 4 knock-in CSQ2-R33Q/R33Q mice, respectively. All experimental protocols were approved by the Institutional Ethical Committees of the Universities of Padova and Chieti. Mice were kept in accredited animal facilities and sacrificed by anaesthetic euthanasia. Four hearts were used for each genotype, and only male mice were selected for the analyses. The samples were homogenised, and the corresponding proteins were quantified using the Lowry biochemical method.

Western Blotting was used for protein level determination. For each sample, 15-50 $\mu \mathrm{g}$ of protein was loaded onto $7.5-10 \%$ SDS-polyacrylamide gels, depending on the protein being investigated. The following dilutions and primary antibodies were used: polyclonal anti-CASQ1/CASQ2 $(1: 1,000)$, monoclonal anti-TR $(1: 1,000)$, polyclonal antiBiP (GRP78) (1:500), and polyclonal anti-CRT (1:1000), all from Affinity Bioreagents (Affinity Bioreagents, Golden, CO); polyclonal anti-GRP94 (1:1,000) from Santa Cruz (Santa Cruz Biotechnology, Santa Cruz, CA); and monoclonal anti-ATF6 from Thermo Scientific (Thermo Fisher Scientific Inc., Waltham, MA). Secondary anti-mouse or anti-rabbit $(1: 5,000)$ alkaline phosphatase-conjugated antibodies were from Sigma (Milan, Italy). After electroblotting on nitrocellulose paper, the equivalence and homogeneity of the loaded samples were verified by staining the nitrocellulose membrane with Ponceau Red. The immunodecorated bands were visualised with a ready-to-use precipitating substrate system for alkaline phosphatase (BCIP/ NBT liquid substrate system; Sigma). Images were obtained with an HP Scanjet scanner and Adobe Photoshop 


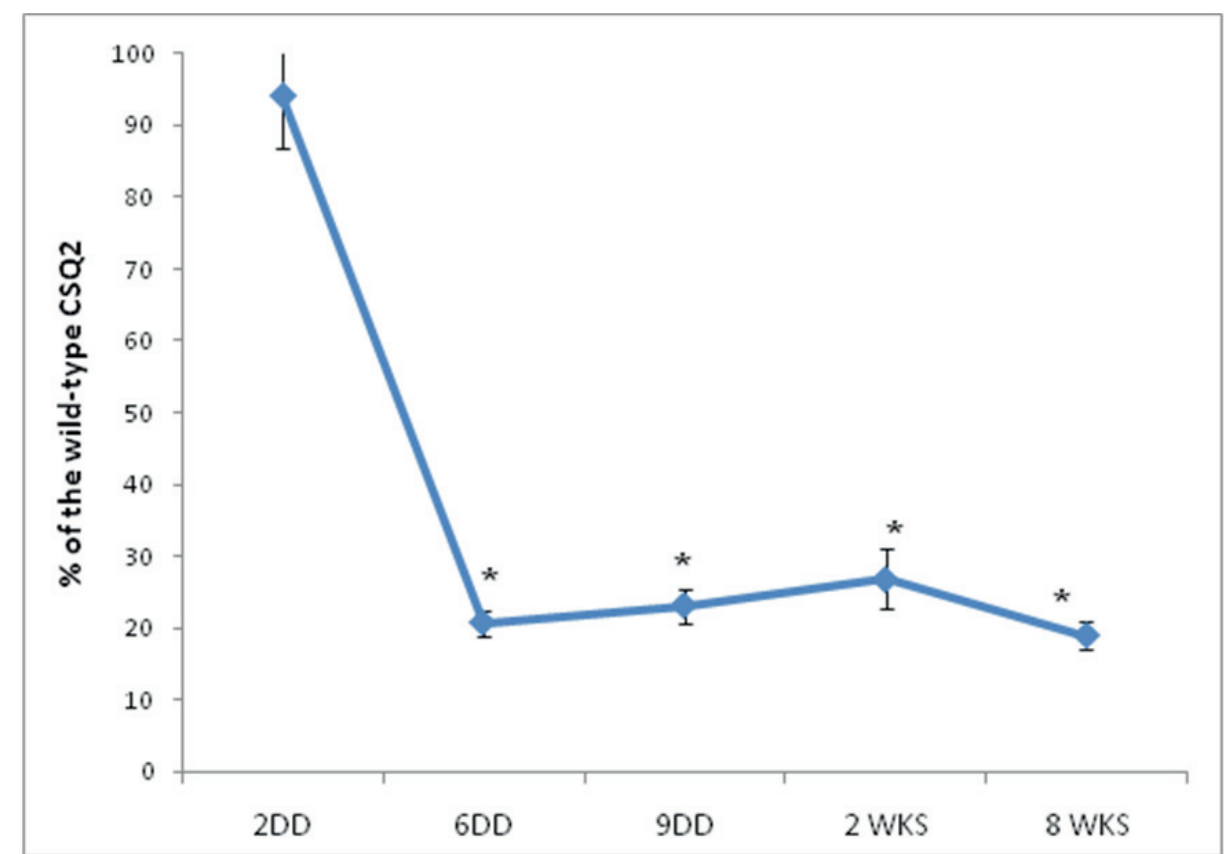

Figure 1: CSQ2 protein levels compared between CSQ2-wt/wt and knock-in CSQ2-R33Q/R33Q mice of different ages (2DD - 2 days, 6DD - 6 days, 9DD - 9 days, 2 WKS - 2 weeks, 8 WKS - 8 weeks). CSQ2 expression levels of homozygous knock-in mice are expressed as the percentage of that of wt mice CSQ2 levels. (") $\mathrm{P}<0.05$ same age comparison between knock-in CSQ2-R33Q/R33Q and CSQ2-wt/wt protein levels.

CS2, version 9.0. Densitometry was performed with Scion Image Software without modification of the images (raw images) to quantify protein band intensities.

Data are expressed as the means \pm SE. Statistical analyses were performed using Origin 8.5 software. Student's $t$ test was used for comparisons between data from wt/wt and knock-in CSQ2-R33Q/R33Q mice. Statistical significance was set at $P<0.05$.

\section{RESULTS}

Western blot data showed that the amount of mutated protein was reduced early after birth, with a drastic reduc- tion at 6 days (Figure 1). Subsequently, increased protein levels were observed at 9 days and 2 weeks. After 2 weeks, decreased levels of CSQ2-R33Q were observed, and protein levels reached a minimum at 8 weeks. Thus, the lowest levels of CSQ2-R33Q expression were observed at 6 days and 8 weeks ( $20 \%$ of the CSQ2 in wt/wt mice).

Triadin levels were also reduced in 8-week- old knockin CSQ2-R33Q/R33Q mice. TD32 is the main cardiac isoform of triadin and is one of the proteins that anchor CSQ2 in proximity to RyR2. In control hearts, the TD32 content increased markedly and quickly after birth (Figure 2A). After 6 days, TD32 expression levels were 5-fold higher than those in 2-day-old wt/wt mice. However, after 6 days, TD32

(A)
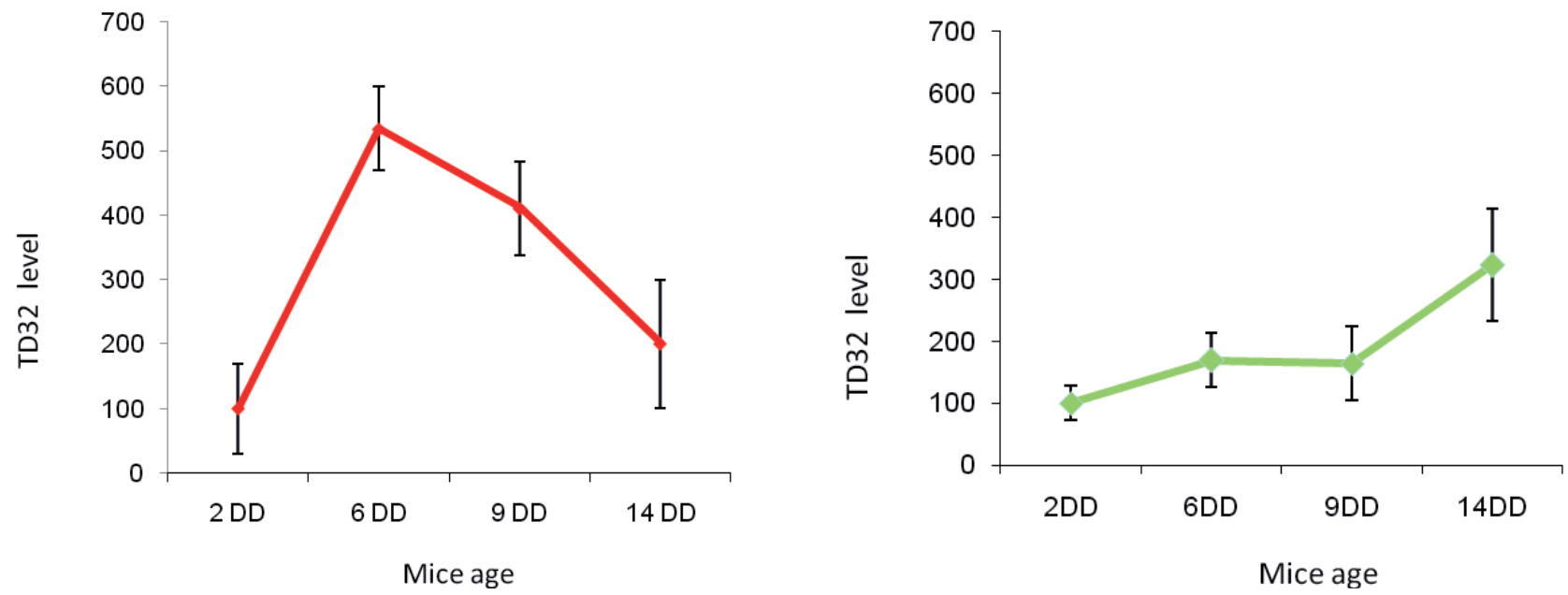

Figure 2: TD32 time course in CSQ2-wt/wt (A) and CSQ2-R33Q/R33Q (B) mice of different ages (2DD - 2 days, 6DD - 6 days, 9DD - 9 days, $14 \mathrm{DD}-2$ weeks) 


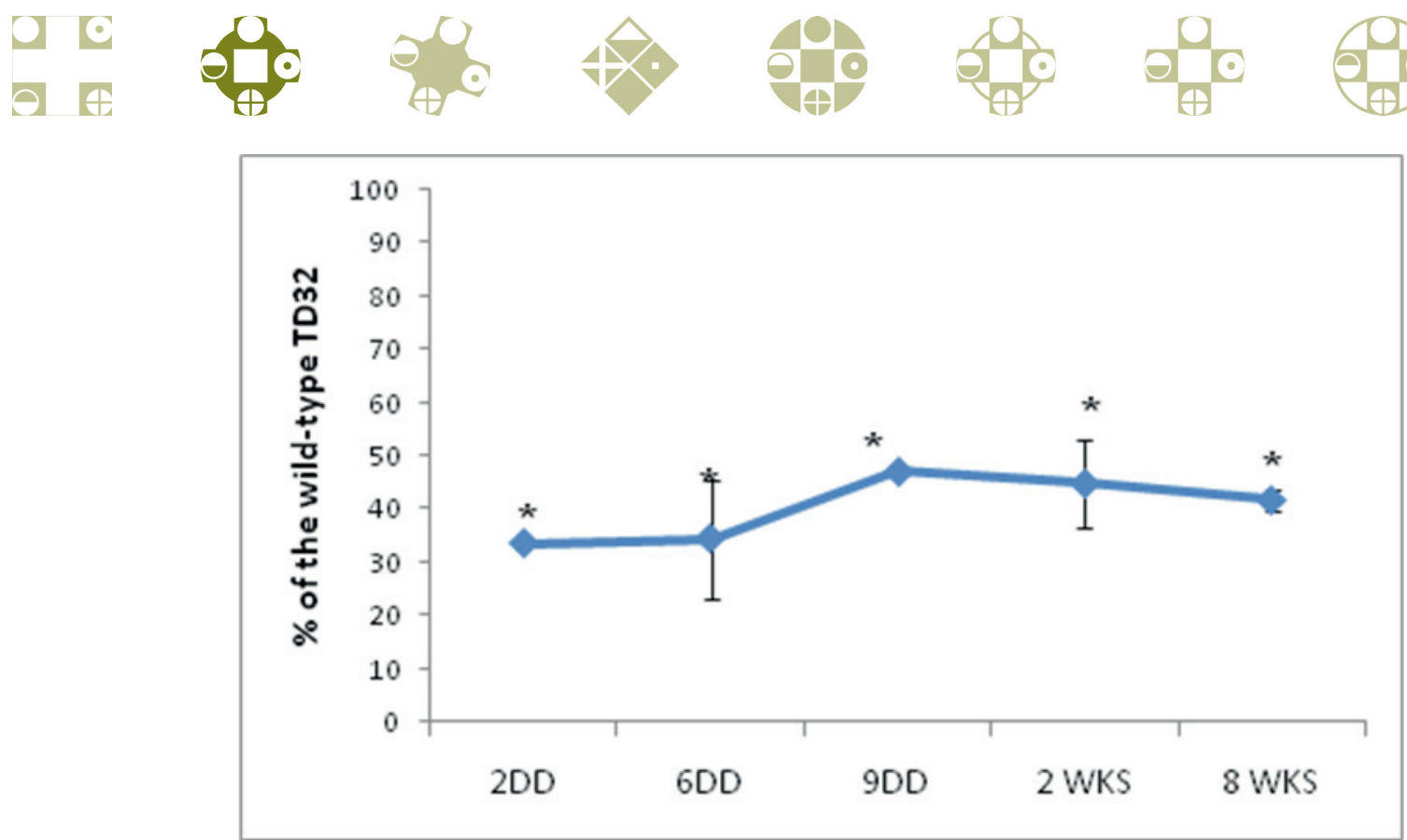

Figure 3: TD32 protein levels compared between wt/wt and knock-in CSQ2-R33Q/R33Q mice of different ages (2DD - 2 days, 6DD - 6 days, 9DD - 9 days, 2 WKS - 2 weeks, 8 WKS - 8 weeks). TD32 expression levels of homozygous knock-in mice are expressed as a percentage of the TD32 levels of wt mice. (*) $\mathrm{P}<0.05$ same age comparison between knock-in CSQ2-R33Q/R33Q and CSQ2-wt/wt protein levels.

levels began to quickly decrease in wt/wt mice. In knock-in mouse hearts, TD32 showed a different expression pattern, increasing slowly over time (Figure 2B). When TD32 levels in knock-in hearts were compared with controls at different ages, a drastic reduction in the protein levels early after birth ( 50\%) was observed, and this reduction remained constant at all ages (Figure 3).

This research was also directed towards the molecular analysis of 3 unfolded protein response (UPR) proximal effectors. The protein expression of one of these proximal effectors, transcriptional factor activating transcription factor 6 (ATF6), was analysed in different age groups of wt/wt and knock-in CSQ2-R33Q/R33Q mice. These analyses showed the presence of increased levels of the active form of ATF6 in 2-week-old knock-in CSQ2-R33Q/R33Q

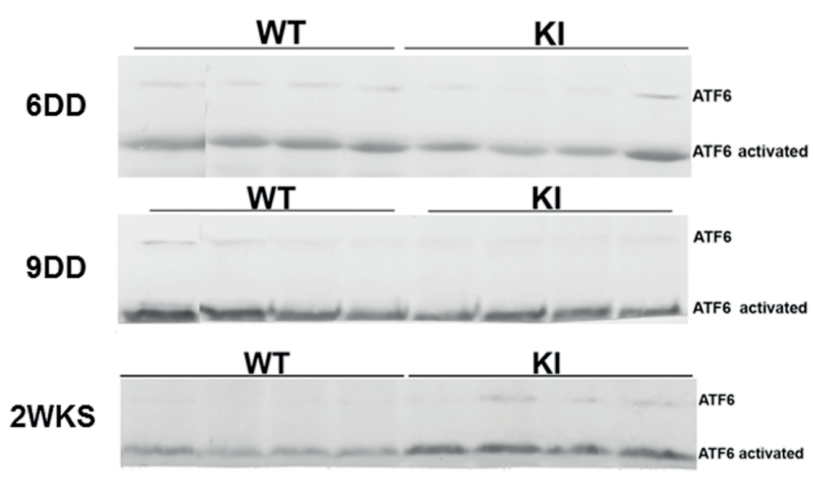

Figure 4: WT and knock-in CSQ2-R33Q/R33Q blots incubated with monoclonal anti-ATF6 antibody, which binds the full-length and active/ cleaved forms of ATF6. Heart proteins from 2 day-, 9 day- and 2 week-old mice were used in these experiments. mice (Figure 4). The transcriptional activation of UPR target genes, including those that function as part of the ER protein-folding machinery (ER chaperones) such as calreticulin (CRT), glucose-regulate protein-78 (GRP78) and glucose-regulate protein-94 (GRP94), was also analysed. The results showed that all three analysed ER chaperones were up-regulated, with peak expression levels observed in the hearts of 2-week-old knock-in CSQ2-R33Q/R33Q mice (Figure 5). For example, GRP78 levels were five times higher in 2-week- old knock-in CSQ2-R33Q/R33Q mice than in wt/wt mice (Figure 5B). Unlike GRP78, GRP94 protein levels remained high in knock-in CSQ2-R33Q/R33Q mice even after 2 weeks (Figure 5C).

\section{DISCUSSION}

Calsequestrin is an acid glycoprotein with a moderate affinity $(\mathrm{Kd}=1 \mathrm{mM})$ and high ability for bindingto $\mathrm{Ca}^{2+}$; it brings the total amount of $\mathrm{Ca}^{2+}$ within the SR to $20 \mathrm{mM}$ and maintains the concentration of free $\mathrm{Ca}^{2+}$ at $1 \mathrm{mM}$ (11). CSQ has a greater ability to bind $\mathrm{Ca}^{2+}$ in its polymeric form in the presence of $1 \mathrm{mM} \mathrm{Ca}^{2+}$. The C-terminus of CSQ contains the highest density of amino acids and is forced to form a $\mathrm{Ca}^{2+}$ - binding pocket in polymeric form (12). CSQ plays an important role as a $\mathrm{Ca}^{2+}$ buffer and regulates the activities of $\mathrm{RyR}$ in relation to the $\mathrm{Ca}^{2+}$ concentration in the SR lumen (13). Furthermore, CSQ, together with triadin and junctin, was proposed to play an important role in SR junction development (14). As proposed by Beard (11), CSQ may also act as a chaperone through its kinase activity to ensure the correct folding of proteins present in the SR lumen and most likely plays an important role in removing toxic substances from the SR 
lumen. CSQ is present in the lumen of the SR terminal cisternae as a linear polymer and is anchored to RyR via two transmembrane proteins, triadin and junctin, forming the $\mathrm{Ca} 2+$ release channel complex (11).

Presently, 8 recessive mutations in the $c s q 2$ gene have been linked to CPVT. Four of them are non-sense mutations that generate premature stop codons, while the other four are point mutations (15-17). The unique characteristic of each mutation can alter the clinical phenotype of the disease (18). In these analyses, we chose specific criteria to obtain complete information regarding postnatal development; thus, we have a detailed picture of the events triggered by the presence of the CSQ2 R33Q point mutation. The first age used was as close to birth as possible (2 days); then, 1 week after birth was used. Nine-day-old mice were chosen for molecular analysis because this age represented an intermediate time point between the first and second weeks. Two weeks after birth was considered a critical time point for the cardiomyocyte based on the results of previous studies (10) that showed the appearance of optimal morphological cardiomyocyte characteristics at this point, which were responsible for the correct functioning of the heart muscle in adulthood. Finally, as reported by Flucher and FranziniArmstrong, 8 weeks was considered a good point to analyse adult hearts (10). The mutated protein levels were analysed first, using the wild- type protein levels as a control. CSQ2R33Q is CSQ2 with a mutated amino acid in position 33; this mutation did not seem to affect the secondary or tertiary conformation of the overall protein (29). The CSQ2 mutation knock-in mouse (9) was characterised in vitro and in vivo and was demonstrated to be an identical copy of the patient phenotype. CSQ2 and triadin protein levels were reduced, while the corresponding mRNAs levels remained unchanged (9). The CSQ2-R33Q protein levels found in this study confirmed the results of Rizzi and colleagues (9), who reported that CSQ2-R33Q proteins levels were significantly lower than wild-type protein levels. Comparison of the results reported in Figures 2A and 2B suggested that TD32 levels decreased due to the lack of functional CSQ2 from birth in the CSQ2-R33Q/R33Q mice. Results from a previous study (19) also showed that CSQ2 protein levels were significantly reduced in adult Trdn -/- mice. The mechanism of the post-transcriptional control of unfolded proteins can explain the reduction of CSQ2-R33Q protein levels without any effect on mRNA content.

ER stress is defined as an imbalance between the load of unfolded proteins that enter the ER and the capacity of the cellular machinery to handle this load; ER stress results in a series of different responses. In eukaryotic cells, the majority of secreted and trans-membrane proteins are synthesised and matured in the ER lumen. Proteins enter the ER as unfolded polypeptide chains. The incorrect folding of nascent proteins may occur in response to many environmental stresses or as a result of mutations that disrupt the protein structure. An imbalance between the load of unfolded proteins entering the ER and the ability of the cell machinery to handle this load is defined as ER stress, which triggers a
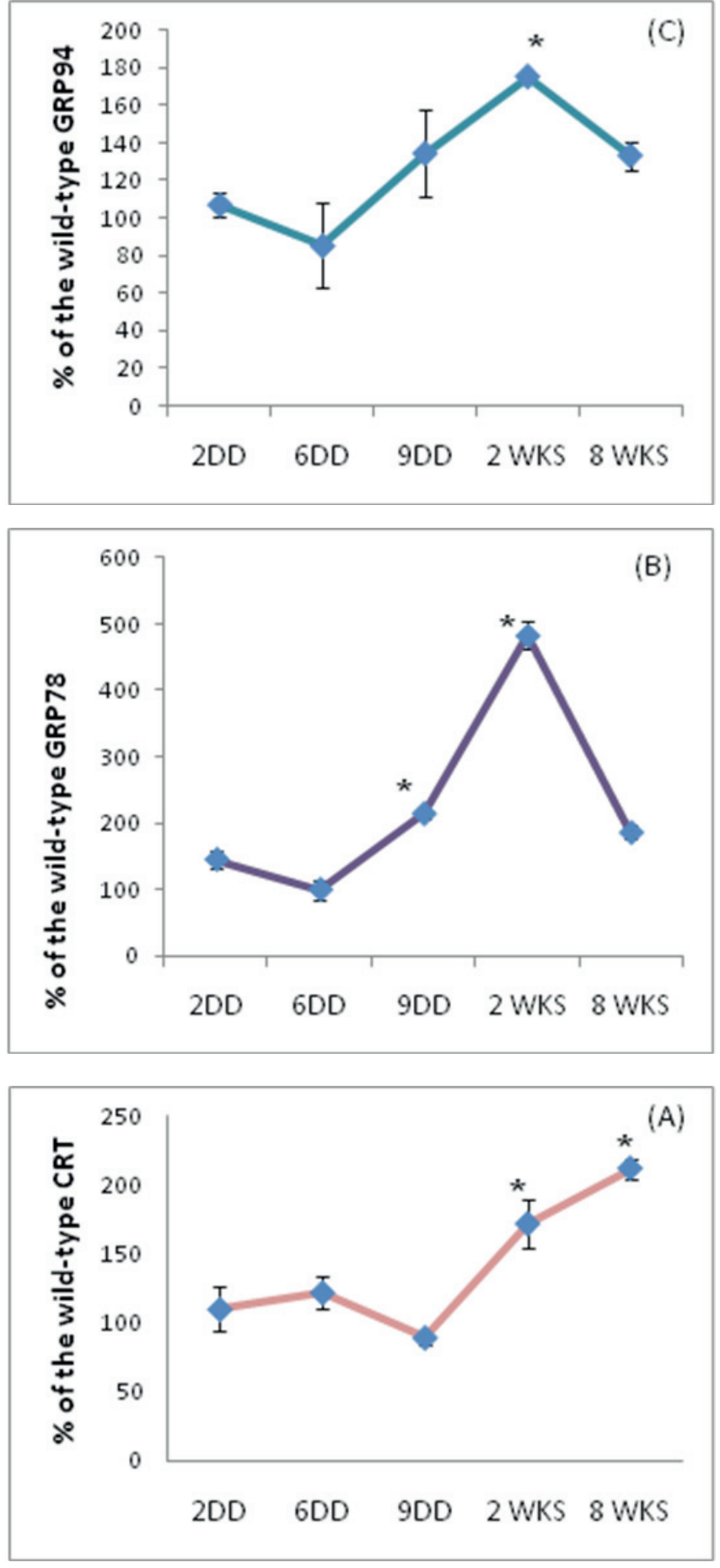

Figure 5: CRT (A), GRP78 (B) and GRP94 (C) protein levels comparisons between wt/wt and knock-in CSQ2-R33Q/R33Q mice of different ages (2DD - 2 days, 6DD - 6 days, 9DD - 9 days, 2 WKS -2 weeks, 8 WKS - 8 weeks). All analysed chaperone expression levels of homozygous knockin mice are expressed as the percentage of those of relative protein levels of wt mice. (") $\mathrm{P}<0.05$ same age comparison between knock-in CSQ2R33Q/R33Q and CSQ2-wt/wt protein levels.

series of responses known as the UPR (20). When ER stress occurs, three ER transmembrane sensors are activated to initiate adaptive responses. These sensors include protein kinase-like ER kinase (PERK), inositol-requiring kinase 1 (IRE1), and ATF6. The N-termini of these transmembrane 
UPR sensors are located inside of the ER lumen and the Ctermini are within the cytosol, thereby connecting the ER lumen to the cytosol. All three sensors are maintained in an inactive state through the interaction of their N-termini with GRP78. When unfolded proteins accumulate in the ER, GRP78 releases these sensors, allowing for their oligomerisation and initiation of the UPR. Under these conditions, GRP78 translocates into the ER lumen, binds proteins and facilitates their folding. At the same time, IRE-1, ATF6, and PERK are activated and induce the transcription of ER stress response genes (21). To analyse the signal transduction cascade involving PERK, attention has focused on the expression of ribosomal protein eIF $2 \alpha$, a translation initiation factor. Phosphorylation of eIF $2 \alpha$ by PERK leads to the decrease of most mRNA translation (22). This first response to ER stress reduces the load of proteins that must enter the ER. This is a transient form of adaptation that is realised by slowing the synthesis and translocation of protein into the ER lumen. Preliminary results have shown an up-regulation of phosphorylated eIF2 $\alpha$ expression in 2-week old knock-in CS2R33Q/R33Q mice. The inactive form, eIF2 $\alpha$-P, lowers the levels of newly synthesised proteins. Subsequently, the capacity of the ER to handle unfolded proteins is increased, representing a more long-term adaptation that entails transcriptional activation of UPR target genes, including those that function as ER chaperones such as CRT, GRP78 and GRP94.

The activated form of ATF6 plays an important role in the synthesis of chaperones such as GRP78 and CRT (23). This was confirmed by experimental data showing that in 2-week-old mice, increased ATF6 levels corresponded to the highest, statistically significant expression levels of GRP78 (Figure 5B) and CRT (Figure 5A). Results in the literature show that ERAD is activated if it is not possible to restore the balance. ERAD provides 1 ) the recognition of incorrectly folded proteins, 2) translocation of such proteins into the cytoplasm, where they are bound to numerous ubiquitin molecules and 3) degradation via the proteasome (24). GRP94 is thought to play an important role in the response to incorrectly folded proteins, participating in their translocation from the ER lumen to the cytosol (25). Unlike GRP78, GRP94 protein levels remained high in knock-in CSQ2-R33Q/R33Q mice even after 2 weeks (Figure $5 \mathrm{C}$ ). This indicated the possible activation of ERAD. Therefore, in accordance with these experimental data, it was speculated that the R33Q mutation induced structural and/or functional changes to CSQ2 that led to UPR activation and subsequent CSQ2 degradation. Thus, the reduction of CSQ2-R33Q might be due to its degradation via ERAD. Proteins with serious folding errors and protein aggregates are degraded by autophagy. In fact, many of the components that mediate autophagy are UPR target genes (26). If ER stress is permanent and irreparable, the process of apoptosis is activated and leads to cell death (27). Thus, it is of extreme interest to extend analyses to markers of autophagy and apoptosis such as CHOP, an ER stress-associated proapoptotic transcription factor (28).

\section{CONCLUSIONS}

These study results showed that mutated CSQ2 levels decreased soon after birth in conjunction with the decreased levels of other important junctional SR proteins such as TD. The up-regulation of proteins associated with the UPR was also observed; this led to ATF6-dependent pathway activation by the UPR. The R33Q mutation induced the decrease of CSQ2 levels through UPR activation and subsequent proteasomal degradation. Further studies are necessary to confirm these results.

\section{REFERENCES}

1. Myerburg RJ, Conde CA, Castellanos A. Survivors of prehospital cardiac arrest. JAMA 1982; 247: 1485-90.

2. Zipes DP, Camm AJ, Borggrefe M, Buxton AE et al. American College of Cardiology/American Heart Association Task Force; European Society of Cardiology Committee for Practice Guidelines; European Heart Rhythm Association; Heart Rhythm Society. ACC/AHA/ESC 2006 guidelines for management of patients with ventricular arrhythmias and the prevention of sudden cardiac death: A report of the American College of Cardiology/American Heart Association Task Force and theEuropean Society of Cardiology Committee for Practice Guidelines (Writing Committee to Develop Guidelines for Management of Patients With Ventricular Arrhythmias and the Prevention of Sudden Cardiac Death) Developed in collaboration with the European Heart Rhythm Association and the Heart Rhythm Society. Circulation 2006; 114: 385-84.

3. Priori SG, Napolitano C, Tiso N, Memmi M, Vignati G, Bloise R, Sorrentino V, Danieli GA. Mutations in the cardiac ryanodine receptor gene (hRyR2) underlie catecholaminergic polymorphic ventricular tachycardia. Circulation 2001; 103: 196-200.

4. Brunello L, Slabaugh JL, Radwanski PB et al. Decreased RyR2 refractoriness determines myocardial synchronization of aberrant $\mathrm{Ca} 2+$ release in a genetic model of arrhythmia. Proc Natl Acad Sci U S A. 2013;110(25): 10312-17.

5. Eldar M, Pras E, Lahat H. A missense mutation in the CASQ2 gene is associated with autosomal-recessive catecholamine-induced polymorphic ventricular tachycardia. Trends Cardiovasc Med_2003; 13: 148-51.

6. Napolitano C, Priori SG. Diagnosis and treatment of catecholaminergic polymorphic ventricular tachycardia. Heart Rhythm 2007; 4: 675-78.

7. Song L, Alcalai R, Arad M, Wolf CM, Toka O, Conner DA, Berul CI, Eldar M, Seidman CE, Seidman JG. Calsequestrin 2 (CASQ2) mutations increase axpression of calreticulin and ryanodine receptors, causing catecholaminergic polymorphic ventricular tachycardia. J Clin Inv 2007; 17: 1814-23. 
8. Cerrone M, Colombi B, Santoro M et al. Bidirectional Ventricular Tachycardia and Fibrillation Elicited in a Knock-In Mouse Model Carrier of a Mutation in the Cardiac Ryanodine Receptor. Circ Res 2005; 96: e77-82.

9. Rizzi N, Liu N, Napolitano C et al. Unexpected structural and functional consequences of the R33Q homozygous mutation in cardiac calsequestrin: a complex arrhythmogenic cascade in a knock in mouse model. Circ Res 2008; 13: 298-306. DOI: 10.1161/ CIRCRESAHA.108.171660.

10. Flucher BE, Franzini-Armstrong C. Formation of junctions involved in excitation-contraction coupling in skeletal and cardiac muscle. Proc Natl Acad Sci USA 1996; 93: 8101-06.

11. Beard NA, Laver DR, Dulhunty AF. Calsequestrin and the calcium release channel of skeletal and cardiac muscle. Prog Biophys Mol Biol 2004; 85: 33-69.

12. Beard NA, Wei L, Dulhunty AF. $\mathrm{Ca}^{(2+)}$ signaling in striated muscle: the elusive roles of triadin, junctin, and calsequestrin. Eur. Biophys. J. 2009; 39: 27-36. DOI: 10.1007/s00249-009-0449-6.

13. Beard NA, Casarotto MG, Wei L, Varsányi M, Laver DR, Dulhunty AF. Regulation of ryanodine receptors by calsequestrin: effect of high luminal $\mathrm{Ca}^{2+}$ and phosphorylation. and phosphorylation. Biophys J 2005; 88: 3444-54.

14. Tijskens P, Jones LR, Franzini-Armstrong C. Junctin and calsequestrin overexpression in cardiac muscle: the role of junctin and the synthetic and delivery pathways for the two proteins. J Mol Cell Cardiol 2003; 35: 961-74.

15. Catterall WA. Structure and regulation of voltage-gated $\mathrm{Ca}^{2+}$ channels. Annu. Rev. Cell. Dev. Biol. 2000; 16: 521-55.

16. Terentyev D, Nori A, Santoro M, Viatchenko-Karpinski $\mathrm{S}$ et al. Abnormal interactions of calsequestrin with the ryanodine receptor calcium release channel complex linked to exercise-induced sudden cardiac death. Circ Res 2006; 98: 1151-58.

17. Kirchhefer U, Wehrmeister D, Postma AV, Pohlentz G, Mormann M, Kucerova D, Müller FU, Schmitz W, Schulze-Bahr E, Wilde AA, Neumann J. The human CASQ2 mutation K206N is associated with hyperglycosylation and altered cellular calcium handling. J Mol Cell Cardiol 2010; 49: 95-105. DOI: 10.1016/j. yjmcc.2010.03.006.
18. di Barletta MR, Viatchenko-Karpinski S, Nori A, Memmi M, Terentyev D, Turcato F, Valle G, Rizzi N, Napolitano C, Gyorke S, Volpe P, Priori SG. Clinical phenotype and functional characterization of CASQ2 mutations associated with Catecholaminergic Polymorphic Ventricular Tachycardia. Circulation 2006; 114: 1012-19.

19. Chopra N, Yang T, Asghari P, Moore ED et al. Ablation of triadin causes loss of cardiac $\mathrm{Ca}^{2+}$ release units, impaired excitation-contraction coupling, and cardiac arrhythmias. Proc Natl Acad Sci USA 2009; 106: 763641. DOI: 10.1073/pnas.0902919106.

20. Groenendyk J, Sreenivasaiah PK, Kim do H, Agellon LB, Michalak M. Biology of endoplasmic reticulum stress in the heart. Circ Res 2010; 107: 1185-97. DOI: 10.1161/CIRCRESAHA.110.227033.

21. Glembotski C. Endoplasmic reticulum stress in the heart. Circ. Res 2007; 101: 975-84.

22. Bertolotti A, Zhang Y, Hendershot LM, Harding HP, Ron D. Dynamic interaction of BiP and ER stress transducers in the unfolded-protein response. Nat Cell Biol 2002; 2: 326-32.

23. Brodsky JL. The protective and destructive roles played by molecular chaperones during ERAD (endoplasmicreticulum-associated degradation). Biochem J 2007; 404: 353-63.

24. Määttänen P, Gehring K, Bergeron JJ, Thomas DY. Protein quality control in the ER: the recognition of misfolded proteins. Semin Cell Dev Biol 2010; 21: 500-511. DOI: 10.1016/j.semcdb.2010.03.006.

25. Bernales, S., McDonald, K.L. and Walter, P. Autophagy counterbalances endoplasmic reticulum expansion during the unfolded protein response. PLoS Biol 2006; 4: 423.

26. Glembotski C. The role of the unfolded protein response in the heart. J Mol Cell Card 2007; 44: 453-59.

27. Gustafsson AB. Bnip3 as a dual regulator of mitochondrial turnover and cell death in the myocardium. Pediatr Cardiol 2011; 32: 267-274. DOI: 10.1007/s00246010-9876-5.

28. Lee JW, Kim WH, Yeo J Jung MH. ER stress is implicated in mitochondrial dysfunction-induced apoptosis of pancreatic beta cells. Mol Cells 2010; 30: 545-549. DOI: $10.1007 / \mathrm{s} 10059-010-0161-5$. 